\title{
RESEARCH
}

Open Access

\section{Salpingo-oophorectomy versus cystectomy in patients with borderline ovarian tumors: a systemic review and meta-analysis on postoperative recurrence and fertility}

Peng Wang ${ }^{*}$ and Lei Fang

\begin{abstract}
Background: To compare the postoperative recurrence and fertility in patients with borderline ovarian tumors (BOTs) who underwent different surgical procedures: salpingo-oophorectomy versus cystectomy.

Methods: Potentially relevant literature from inception to Nov. 06, 2020, were retrieved in databases including Cochrane Library, EMBASE (Ovid), and MEDLINE (Pubmed). We applied the keywords "fertility-sparing surgery," or "conservative surgery," or "cystectomy," or "salpingo-oophorectomy," or "oophorectomy," or "adnexectomy," or "borderline ovarian tumor" for literate searching. Systemic reviews and meta-analyses were performed on the postoperative recurrence rates and pregnancy rates between patients receiving the two different surgical methods. Begger's methods, Egger's methods, and funnel plot were used to evaluate the publication bias.

Result: Among the sixteen eligible studies, the risk of recurrence was evaluated in all studies, and eight studies assessed the postoperative pregnancy rates in the BOT patients. A total of 1839 cases with borderline ovarian tumors were included, in which 697 patients (37.9\%) received unilateral salpingo-oophorectomy and 1142 patients (62.1\%) underwent unilateral/bilateral cystectomy. Meta-analyses showed that BOT patients with unilateral/bilateral cystectomy had significantly higher recurrence risk (OR=2.02, 95\% Cl: 1.59-2.57) compared with those receiving unilateral salpingo-oophorectomy. Pooled analysis of four studies further confirmed the higher risk of recurrence in patients with cystectomy ( $\mathrm{HR}=2.00,95 \% \mathrm{Cl}$ : 1.11-3.58). In addition, no significant difference in postoperative pregnancy rate was found between patients with the two different surgical procedures ( $\mathrm{OR}=0.92,95 \% \mathrm{Cl}$ : 0.60-1.42). Conclusion: Compared with the unilateral/bilateral cystectomy, the unilateral salpingo-oophorectomy significantly reduces the risk of postoperative recurrence in patients with $\mathrm{BOT}$, and it does not reduce the pregnancy of patients after surgery.
\end{abstract}

Trial registration: PROSPERO CRD42021238177

Keywords: Salpingo-oophorectomy, Cystectomy, Borderline ovarian tumors, Fertility, Meta-analysis

* Correspondence: roc_king@sina.com

Beijing Obstertrics and Gynecology Hospital, Capital Medical University, No.

251 Yao Jiayuan Road, Chaoyang District, Beijing 100026, China

(c) The Author(s). 2021 Open Access This article is licensed under a Creative Commons Attribution 4.0 International License, which permits use, sharing, adaptation, distribution and reproduction in any medium or format, as long as you give appropriate credit to the original author(s) and the source, provide a link to the Creative Commons licence, and indicate if changes were made. The images or other third party material in this article are included in the article's Creative Commons licence, unless indicated otherwise in a credit line to the material. If material is not included in the article's Creative Commons licence and your intended use is not permitted by statutory regulation or exceeds the permitted use, you will need to obtain permission directly from the copyright holder. To view a copy of this licence, visit http://creativecommons.org/licenses/by/4.0/ The Creative Commons Public Domain Dedication waiver (http://creativecommons.org/publicdomain/zero/1.0/) applies to the data made available in this article, unless otherwise stated in a credit line to the data. 


\section{Introduction}

Borderline ovarian tumors (BOTs) refer to the tumor of the ovarian with a property between benign and malignant masses, which was first discovered by Tayor in 1929 [1]. It was estimated that about 2.5 to 5.5 per 100,000 women were diagnosed as BOTs every year $[2,3]$. According to the classification proposed by the World Health Organization, BOTs are an independent class of ovarian tumors distinguished from epithelial ovarian tumors in clinical and pathological characteristics [4], with an increasing trend of incidence year by year [5]. For the treatment of BOT, surgery is the preferred method for patients at early stages though debates are always exited for different procedures [6]. The last few decades witnessed the rapid development of nanotechnology, a promising method for patients with BOT. This strategy applied particles at nano-levels to deliver drugs to the tumors for local treatment. These particles include nanoparticles, nano-micelles, nanocapsules, and liposomes, which have obtained satisfied effects for the diagnosis and treatment of cancers [7]. BOTs are more commonly discovered in women at premenopausal status, especially before 40 years old [8,9]. At this special life stage, many diagnosed women express strong expectation of preserving fertility. Therefore, a fertilitysparing treatment (FST) is particularly important for these patients.

Previous studies showed that FST can be tolerated in BOT patients and the ability of pregnancy was persevered $[10,11]$, while other studies revealed that the risk of recurrence, or even death, may be increased in patients receiving FST [12-14]. As we known, FST has various surgical procedure types including salpingooophorectomy and cystectomy. Currently, there is no consensus on the selection of preferred surgical procedures for patients with BOT. Some researchers believed that salpingo-oophorectomy was showed a lower recurrence rate, thereby tending to select salpingooophorectomy in these patients, while other surgeons proposed that resection of one ovary may lead to declined possibility of pregnancy, thus advocating the cystectomy [15]. Given these inconsistent results and opinions, it is needed to comprehensively summarize and analyze the current evidences on this topic, thereby clarifying the advantages and disadvantages of these two surgical methods.

In order to assess the postoperative recurrence and fertility in patients with BOTs who underwent salpingooophorectomy or cystectomy, we conducted this systemic review and meta-analysis for the currently available studies. It is hoped to provide clinical evidences for surgeons to select better surgical procedures for BOT patients.

\section{Methods}

This systemic review and meta-analysis was performed in strict accordance with the Preferred Reporting Items for Systematic Reviews and Meta Analyses (PRISMA) [16].

\section{Literature search}

All potentially relevant literatures from inception to Nov. 06, 2020, were searched in the databases including Cochrane Library, EMBASE (Ovid), and MEDLINE (Pubmed) [17]. The MeSH words "fertility," or "postoperative recurrence," or "conservative surger," or "cystectomy," or "salpingo-oophorectomy," or "oophorectomy," or "adnexectomy," or "borderline ovarian tumor," or "systemic review," or "meta-analysis" were used for literate retrieval.

\section{Eligibility of studies and data extraction}

Two authors independently screened the articles. The preliminarily searched literature was firstly screen with tittle, and then selected by reading the abstract. After a comprehensive review of the full text of selected literature, articles that met the inclusion and exclusion criteria were finally included for data extraction. If there was inconsistency about article inclusion, it was determined by an in-depth discussion of the two authors. Only the study with the largest sample size was included if there were many studies with the same population for investigation. The inclusion criteria for eligible literature were as follows: (1) all patients were pathologically confirmed as BOTs after surgery; (2) studies comparing the oncological outcomes and the postoperative pregnancy of two FSTs, that were the unilateral/bilateral cystectomy versus unilateral salpingo-oophorectomy, in patients with BOTs; (3) studies with sample size $\geq 30$. Exclusion criteria were as follows: (1) studies that did not provide data of relevant clinical outcomes; (2) studies with incomplete data; (3) reviews, meta-analysis, case reports, meeting abstracts, and other types of articles that were inappropriate for this study. A predesigned form was used for data extraction of the studies. Here, we collected the author name, country, study period, age, sample size, surgical procedures, stage, follow-up, recurrence, 5-year disease-free survival, interval to recurrence, pregnancy, time to pregnancy, and risk of bias.

\section{Main outcomes}

In this study, the main clinical outcomes for metaanalysis include the rate of postoperative recurrence and the rate of pregnancy in BOT patients who underwent unilateral/bilateral cystectomy or unilateral salpingooophorectomy. 


\section{Assessment of literature quality}

To evaluate the quality of the included literature, we systemically collected the parameters of each study such as country, study period, sample size, follow-up, and so on. The risk of bias in non-randomized studies of interventions (ROBINS-I) was used for assessing the risk of bias. The publication bias was assessed by Begger's method, Egger's method, or funnel plot.

\section{Data analyses}

All the statistical analyses were conducted with the Stata 14.0 software. In order to compare the postoperative recurrence and pregnancy between unilateral/bilateral cystectomy and unilateral salpingo-oophorectomy, pooled odds ratios (ORs) or hazard ratios (HRs) with the 95\% confidence interval were calculated in metaanalyses. The heterogeneity of studies was assessed by the $I^{2}$ test or Cochran $Q$ test. $I^{2}>50 \%$ or $P<0.1$ indicated the existence of significant heterogeneity, and the random-effects model was applied for meta-analysis. In other situations, the fixed random-effects model was used.

\section{Results}

\section{General characteristics of included studies}

After the preliminary retrieval with the keywords in the databases, 425 articles with potential relevance were obtained. A total of 380 articles were excluded after reading the title and abstract by the two investigators. For the remaining 45 articles, the full texts were carefully reviewed, and 29 articles (including 5 reviews or metaanalysis, 16 articles with incomplete data or irrelevance, and 8 studies with a sample size less than 40) did not meet the criteria for eligibility. Eventually, 16 studies were included in the data synthesis of meta-analysis (Table 1). All the studies were retrospective cohort studies published between 2001 and 2019. A total of 1839 cases with borderline ovarian tumors were included, in which 697 patients $(37.9 \%)$ received unilateral salpingooophorectomy and 1142 patients $(62.1 \%)$ underwent unilateral/bilateral cystectomy. The sample sizes of the included studies were from 31 to 535 cases.

\section{Comparison of postoperative recurrence risk between patients with unilateral salpingo-oophorectomy and unilateral/bilateral cystectomy}

Sixteen studies compared the risk of BOT recurrence between patients underwent unilateral salpingooophorectomy and unilateral/bilateral cystectomy (Table 2) $[12,18-32]$, and the results of the pooled analysis revealed that the rate of tumor relapse was significantly higher in patients receiving unilateral/bilateral cystectomy (OR=2.02, 95\% CI: 1.59-2.57, $P<0.001$, Fig. 1 ). Begger's and Egger's methods were used to evaluate the publication bias of the literature. The plots did not show significant publication bias (Supplementary Figures 1 and 2). A total of four studies calculated the hazards ratio (HR) and $95 \% \mathrm{CI}$ of unilateral/bilateral cystectomy for tumor recurrence compared with unilateral salpingooophorectomy [21, 26-28]. Meta-analysis further confirmed that cystectomy was associated with a higher recurrence rate of BOT $(\mathrm{HR}=2.00,95 \% \mathrm{CI}: 1.11-3.58, P$ $<0.001$, Fig. 2). A funnel plot was drawn and no significant publication bias was presented (Supplementary Figure 3).

\section{Comparison of postoperative fertility between patients with different surgical procedures}

Eight studies evaluated the postoperative pregnancy rates of patients after fertility-sparing treatment $[20,21$, $23,25-27,31,32]$. A pooled analysis did not reveal a significant difference in the postoperative pregnancy rates between patients underwent unilateral/bilateral cystectomy (OR=0.92, 95\% CI: 0.60-1.42, $P>0.05$, Fig. 3), suggesting that the two surgical procedures had similar effects on the postoperative fertility in patients with BOT. No significant publication bias was presented on the funnel plot (Supplementary Figure 4).

\section{Discussion}

In this systemic review and meta-analysis, we found that BOT patients with unilateral/bilateral cystectomy were showed a higher risk of relapse compared with those who underwent unilateral salpingo-oophorectomy. Moreover, there was no significant difference in the postoperative pregnancy rates between patients with the two different surgical procedures. Our study provides valid evidence on the clinical outcomes, as well as effects on pregnancy, of the unilateral/bilateral cystectomy and salpingo-oophorectomy in patients with BOTs. It is of great significance to verify the advantages of salpingooophorectomy in clinical practices.

The typical features of BOTs are proliferation of tumor cells and the atypia of the nucleus, while the stroma is not invaded. It is more common in young females and the prognosis is better than that of invasive epithelial ovarian cancers [33]. It was reported that the patients with BOTs diagnosed at childbearing age accounted for about $34 \%$ of all the patients [34]. One of the obstacles influencing the prognosis of BOTs is the relapse. It was estimated that the rate of relapse in BOT patients was about $0 \%$ to $25 \%$, in which $1 \%$ to $3 \%$ of the relapse were invasive [35]. In 2007, Silva et al. found that the recurrence of BOTs varied along with follow-up duration, with a 5-year, 10-year, 15-year, and more than 15year relapse rate of $10 \%, 19 \%, 10 \%$, and $5 \%$, respectively [36]. However, one study found that the postoperative pregnancy rate was declined to $34 \%$ while the risk of 
Table 1 Baseline characteristics of included studies

\begin{tabular}{|c|c|c|c|c|c|c|c|c|c|c|c|c|}
\hline Study & Country & $\begin{array}{l}\text { Study } \\
\text { period }\end{array}$ & $\begin{array}{l}\text { Age } \\
\text { median } \\
\text { (range) }\end{array}$ & $\begin{array}{l}\text { Sample } \\
\text { size (Cy } \\
\text { vs SO) }\end{array}$ & Stage & $\begin{array}{l}\text { Follow-up } \\
\text { median } \\
\text { (range) }\end{array}$ & $\begin{array}{l}\text { Recurrence } \\
\text { (Cy vs SO, } \\
\%)\end{array}$ & $\begin{array}{l}\text { 5-DFS } \\
\text { (Cy vs } \\
\text { SO, \%) } \\
\end{array}$ & $\begin{array}{l}\text { Interval to } \\
\text { recurrence }\end{array}$ & $\begin{array}{l}\text { Pregnancy } \\
\text { (Cy vs SO, } \\
\%)\end{array}$ & $\begin{array}{l}\text { Time to } \\
\text { pregnancy }\end{array}$ & Risk \\
\hline $\begin{array}{l}\text { Marchette } \\
\text { et al. }\end{array}$ & Italy & $\begin{array}{l}1978- \\
2013\end{array}$ & $\begin{array}{l}29.8 \\
(25.3- \\
34.4)\end{array}$ & $\begin{array}{l}535(264 / \\
271)\end{array}$ & I-IV & $\begin{array}{l}12.4 \text { y (11.8- } \\
13.3)\end{array}$ & $\begin{array}{l}54.7 \% \text { vs } \\
45.3 \%\end{array}$ & $\begin{array}{l}\text { HR: } 1.34 \\
\left(0.98^{-}\right. \\
1.81)\end{array}$ & N/A & $\begin{array}{l}52.4 \% \text { vs } \\
47.6 \%\end{array}$ & N/A & M \\
\hline Tsai et al. & Taiwan & $\begin{array}{l}2000- \\
2006\end{array}$ & $\begin{array}{l}\text { Mean } \pm \\
\text { SD: } 40.7 \pm \\
16.5\end{array}$ & $31(7 / 24)$ & $|-|||$ & $\begin{array}{l}56.5 \mathrm{mo} \\
(12-103)\end{array}$ & $22.6 \%$ & N/A & $\begin{array}{l}25.1 \mathrm{mo} \\
(10-56)\end{array}$ & $19.4 \%$ & N/A & M \\
\hline Yinon et al. & Israel & $\begin{array}{l}1979- \\
2014\end{array}$ & $\begin{array}{l}28(13- \\
44)\end{array}$ & $62(22 / 40)$ & I & $\begin{array}{l}36 \mathrm{mo}(7- \\
81)\end{array}$ & $\begin{array}{l}22.2 \% \text { vs } \\
27.5 \%\end{array}$ & N/A & $\begin{array}{l}23.6 \text { vs } 41 \\
\text { mo }\end{array}$ & $\begin{array}{l}22.7 \% \text { vs } \\
47.5 \%\end{array}$ & $\begin{array}{l}42 \mathrm{mo}(9- \\
144)\end{array}$ & M \\
\hline Morice et al. & France & $\begin{array}{l}1965- \\
1997\end{array}$ & $\begin{array}{l}\text { Mean } \pm \\
\text { SD: } 32 \pm \\
11.4\end{array}$ & $49(11 / 38)$ & $|-|||$ & $\begin{array}{l}109 \text { mo (24- } \\
300)\end{array}$ & $\begin{array}{l}36.3 \% \text { vs } \\
15.1 \%\end{array}$ & N/A & $\begin{array}{l}38 \mathrm{mo}(1- \\
243)\end{array}$ & $28.6 \%$ & $\begin{array}{l}37.5 \text { mo (3- } \\
84)\end{array}$ & M \\
\hline $\begin{array}{l}\text { Romagnolo } \\
\text { et al. }\end{array}$ & Italy & $\begin{array}{l}1992- \\
2004\end{array}$ & $\begin{array}{l}44(20- \\
88)\end{array}$ & $53(21 / 32)$ & $|-|||$ & $\begin{array}{l}44 \mathrm{mo}(6- \\
122)\end{array}$ & $28 \%$ vs $23 \%$ & N/A & N/A & $15.1 \%$ & N/A & $\mathrm{H}$ \\
\hline $\begin{array}{l}\text { Poncelet } \\
\text { et al. }\end{array}$ & France & $\begin{array}{l}1990- \\
2000\end{array}$ & $\begin{array}{l}\text { Mean } \pm \\
\text { SD: } 30.6 \pm \\
7.8\end{array}$ & $\begin{array}{l}133(33 / \\
100)\end{array}$ & I & $\begin{array}{l}19 \mathrm{mo}(6- \\
243)\end{array}$ & $\begin{array}{l}30.3 \% \text { vs } \\
11 \%\end{array}$ & N/A & N/A & N/A & N/A & M \\
\hline Chen et al. & China & $\begin{array}{l}2003- \\
2010\end{array}$ & $\begin{array}{l}30.2(11- \\
49)\end{array}$ & $\begin{array}{l}122(75 / \\
47)\end{array}$ & $|-|||$ & $\begin{array}{l}\text { Cy: } 22.7 \mathrm{mo} \\
\text { SO: } 48.0 \mathrm{mo}\end{array}$ & $9.3 \%$ vs $2.1 \%$ & N/A & $\begin{array}{l}22.7 \mathrm{vs} \\
48.0 \mathrm{mo}\end{array}$ & $\begin{array}{l}77.3 \% \text { vs } \\
76.9 \%\end{array}$ & N/A & M \\
\hline Lee et al. & Korea & $\begin{array}{l}1998- \\
2014\end{array}$ & $\begin{array}{l}\text { Cy: } 28 \\
(14-40) \\
\text { SO: } 30 \\
(21-38)\end{array}$ & $\begin{array}{l}108(19 / \\
89)\end{array}$ & I & $\begin{array}{l}\text { Cy: } 25.4 \mathrm{mo} \\
\text { SO: } 37.4 \mathrm{mo}\end{array}$ & $\begin{array}{l}15.8 \% \text { vs } \\
3.4 \%\end{array}$ & $\begin{array}{l}78.8 \% \text { vs } \\
95.7 \%\end{array}$ & $24 \mathrm{mo}$ & $\begin{array}{l}87.5 \% \text { vs } \\
79.2 \%\end{array}$ & N/A & M \\
\hline Fang et al. & China & $\begin{array}{l}1996- \\
2016\end{array}$ & N/A & $45(7 / 38)$ & $|-|||$ & $\begin{array}{l}46.5 \mathrm{mo} \\
(13-146)\end{array}$ & $63 \%$ vs $24 \%$ & $\begin{array}{l}\text { HR: } 3.30 \\
(1.34- \\
8.14)\end{array}$ & $\begin{array}{l}27 \text { vs } 55 \\
\text { mo }\end{array}$ & $67 \%$ vs $69 \%$ & $\mathrm{~N} / \mathrm{A}$ & M \\
\hline Uzan et al. & France & $\begin{array}{l}1999- \\
2009\end{array}$ & $\begin{array}{l}29(14- \\
65)\end{array}$ & $\begin{array}{l}119(69 / \\
50)\end{array}$ & I & $\begin{array}{l}45 \mathrm{mo}(12- \\
120)\end{array}$ & $\begin{array}{l}37.7 \% \text { vs } \\
24 \%\end{array}$ & N/A & N/A & $27 \%$ & $\begin{array}{l}48 \text { vs } 27 \\
\text { mo }\end{array}$ & M \\
\hline $\begin{array}{l}\text { De laco } \\
\text { et al. }\end{array}$ & Italy & $\begin{array}{l}1985- \\
2006\end{array}$ & $\begin{array}{l}45.5(14- \\
85)\end{array}$ & $85(35 / 50)$ & $|-|||$ & $\begin{array}{l}60.5 \text { mo (4- } \\
240)\end{array}$ & $\begin{array}{l}34.3 \% \text { vs } \\
20.0 \%\end{array}$ & $\begin{array}{l}59.6 \% \text { vs } \\
78.4 \%\end{array}$ & $25.1 \mathrm{mo}$ & N/A & N/A & M \\
\hline Song et al. & Korea & $\begin{array}{l}1997- \\
2009\end{array}$ & $\begin{array}{l}29(10- \\
83)\end{array}$ & $\begin{array}{l}155 \text { (38/ } \\
117)\end{array}$ & $|-|||$ & $\begin{array}{l}56 \mathrm{mo}(0.6- \\
155.9)\end{array}$ & $\begin{array}{l}13.2 \% \text { vs } \\
5.9 \%\end{array}$ & N/A & N/A & $88.2 \%$ & $\begin{array}{l}28 \mathrm{mo} \text { (8- } \\
97)\end{array}$ & M \\
\hline $\begin{array}{l}\text { Burgmann } \\
\text { et al. }\end{array}$ & USA & $\begin{array}{l}1982- \\
2005\end{array}$ & $\begin{array}{l}33(12- \\
95)\end{array}$ & $\begin{array}{l}190(47 / \\
143)\end{array}$ & I & N/A & $23 \%$ vs $7 \%$ & N/A & 2.6 vs 4.8 y & N/A & N/A & $\mathrm{H}$ \\
\hline Pektas et al. & Turkey & $\begin{array}{l}1999- \\
2009\end{array}$ & $\begin{array}{l}\text { Mean } \pm \\
\text { SD: } 37.4 \pm \\
9.5\end{array}$ & $50(14 / 36)$ & $|-|||$ & $\begin{array}{l}61.0 \pm 23.2 \\
\text { mo }\end{array}$ & $\begin{array}{l}14.3 \% \text { vs } \\
2.8 \%\end{array}$ & $\begin{array}{l}\text { Mean } \\
\text { DFS: } \\
60.7 \pm \\
23.2\end{array}$ & N/A & $52.3 \%$ & N/A & M \\
\hline Koskas et al. & France & $\begin{array}{l}1997- \\
2004\end{array}$ & $\begin{array}{l}\text { Mean } \pm \\
\text { SD: } 26.5 \pm \\
6.4\end{array}$ & $31(12 / 19)$ & I & $\begin{array}{l}59 \mathrm{mo}(12- \\
182)\end{array}$ & $\begin{array}{l}41.7 \% \text { vs } \\
5.3 \%\end{array}$ & $\begin{array}{l}49.1 \% \text { vs } \\
94.7 \%\end{array}$ & $\mathrm{~N} / \mathrm{A}$ & $\begin{array}{l}41.8 \text { vs } \\
45.9 \%\end{array}$ & N/A & M \\
\hline $\begin{array}{l}\text { Ureyen } \\
\text { et al. }\end{array}$ & Turkey & $\begin{array}{l}1990- \\
2014\end{array}$ & $\begin{array}{l}38.5(18- \\
74)\end{array}$ & $71(23 / 48)$ & $|-|||$ & $\begin{array}{l}57 \text { mo (3- } \\
270)\end{array}$ & $\begin{array}{l}17.4 \% \text { vs } \\
8.3 \%\end{array}$ & N/A & N/A & N/A & N/A & $\mathrm{H}$ \\
\hline
\end{tabular}

Cy cystectomy (unilateral and/or bilateral), SO unilateral salpingo-oophorectomy, mo months, $D F S$ disease-free survival, $H R$ hazard ratio, $M$ moderate risk, $L$ low risk, $H$ high risk

relapse was increased to $38 \%$ in $\mathrm{BOT}$ patients at late stages [15]. A pooled analysis revealed a relapse rate of $16 \%$ including 5 cases of death and $48 \%$ of the patients were pregnant after FST [37]. Since the large number of BOT patients at a life stage with the expectation of fertility, treatment methods were increasingly from radical resection to a more conservation strategy [10]. In particular, FST is a method with satisfied safety, and has been widely used in ovarian tumors [1-3]. Even though the FST was already recognized as an important strategy in patients with BOTs, studies for comparing the clinical outcomes and prognosis between different FST subtypes such as cystectomy and salpingo-oophorectomy are rare.

Cystectomy has the advantage of retaining more ovarian tissues, which is proposed to greatly increase the possibility of pregnancy after surgery. One study 
Table 2 Subgroup analysis for the comparison of recurrence between salpingo-oophorectomy and cystectomy in borderline ovarian tumors

\begin{tabular}{|c|c|c|c|c|c|}
\hline \multirow{2}{*}{$\begin{array}{l}\text { Subgroup } \\
\text { analysis }\end{array}$} & \multirow[t]{2}{*}{ Studies } & \multicolumn{2}{|l|}{ Pooled results } & \multicolumn{2}{|c|}{ Heterogeneity } \\
\hline & & Effect size $(95 \% \mathrm{Cl})$ & $P$ value & $P^{2}$ & $P$ value \\
\hline Region & & OR & & & \\
\hline Eastern & 5 & $2.02(2.21-9.40)$ & $<0.001$ & $0 \%$ & 0.443 \\
\hline Western & 11 & $1.83(1.42-2.36)$ & $<0.001$ & $42.3 \%$ & 0.067 \\
\hline FIGO stage & & OR & & & \\
\hline 1 & 7 & $3.16(1.92-5.20)$ & $<0.001$ & $21.7 \%$ & 0.264 \\
\hline$|-|||$ & 9 & $1.78(1.35-2.33)$ & $<0.001$ & $43.6 \%$ & 0.077 \\
\hline Sample size & & OR & & & \\
\hline$\geq 100$ & 7 & $1.85(1.40-2.44)$ & $<0.001$ & $36.3 \%$ & 0.151 \\
\hline$<100$ & 9 & $2.64(1.64-4.23)$ & $<0.001$ & $47.1 \%$ & 0.057 \\
\hline Publication year & & OR & & & \\
\hline After 2010 & 10 & $1.89(1.42-2.50)$ & $<0.001$ & $41.0 \%$ & 0.084 \\
\hline Before 2010 & 6 & $2.43(1.56-3.79)$ & $<0.001$ & $47.0 \%$ & 0.093 \\
\hline Follow-up period & & OR & & & \\
\hline$\geq 50$ months & 8 & $1.84(1.37-2.47)$ & $<0.001$ & $57.9 \%$ & 0.020 \\
\hline$<50$ months & 7 & $2.16(1.38-3.39)$ & 0.001 & $7.1 \%$ & 0.374 \\
\hline
\end{tabular}

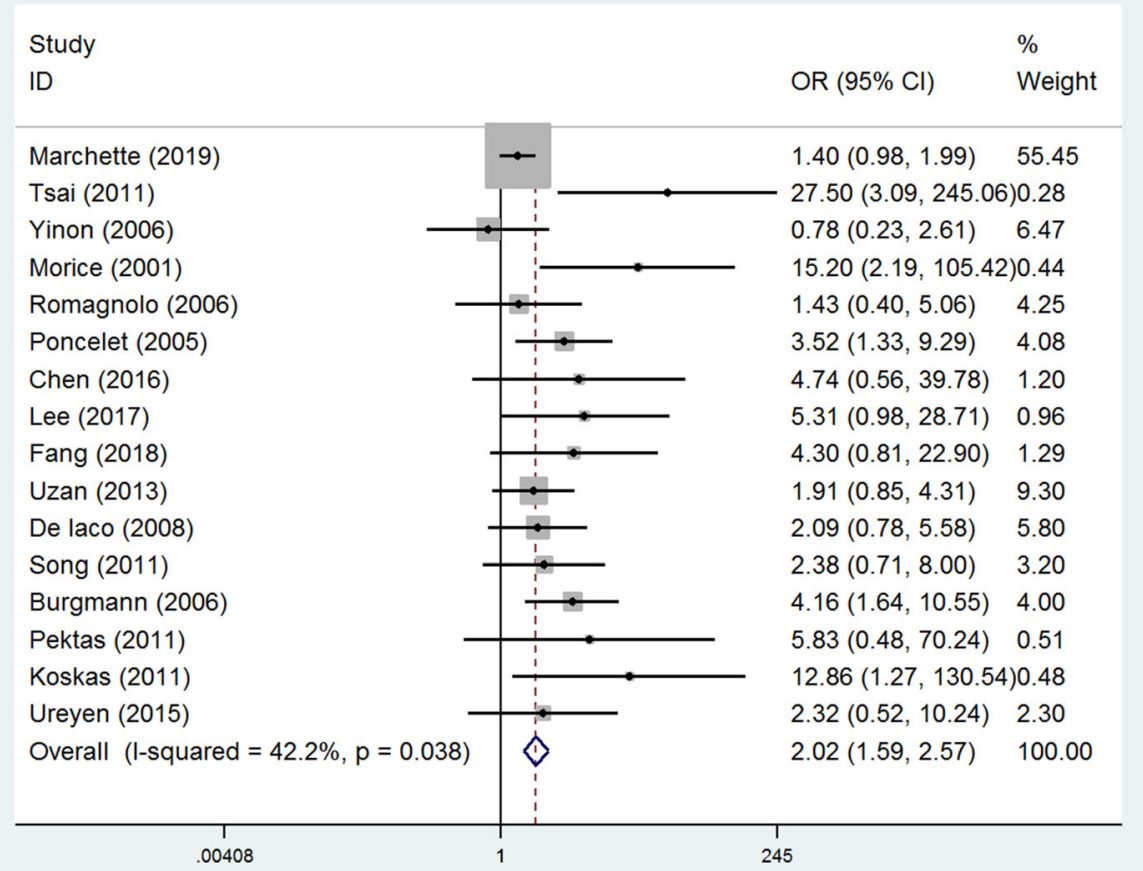

Fig. 1 Forest plots of the odds ratios of postoperative recurrence in BOT patients. Sixteen studies compared the risk of BOT recurrence in between patients underwent unilateral salpingo-oophorectomy and unilateral/bilateral cystectomy. The results of the pooled analysis revealed that the rate of tumor relapse was significantly higher in patients receiving unilateral/bilateral cystectomy had a significantly higher risk of tumor relapse 
Study

ID
HR $(95 \% \mathrm{Cl}) \quad$ Weight

\begin{tabular}{llrl}
\hline Marchette (2019) & $1.34(0.98,1.81)$ & 38.05 \\
Tsai (2011) & $3.70(1.34,8.14)$ & 21.14 \\
Fang (2018) & $1.36(0.79,2.35)$ & 31.05 \\
De laco (2008) & & & \\
Overall (I-squared $=66.9 \%, p=0.028)$ & $2.00(1.11,3.58)$ & 100.00 \\
NOTE: Weights are from random effects analysis & & & \\
\hline
\end{tabular}

Fig. 2 Forest plots of the hazard ratios of postoperative recurrence in BOT patients. Four studies calculated the hazards ratio (HR) and 95\% Cl of unilateral/bilateral cystectomy for risk of tumor recurrence compared with unilateral salpingo-oophorectomy. Results confirmed that cystectomy was associated with a higher recurrence rate of BOT

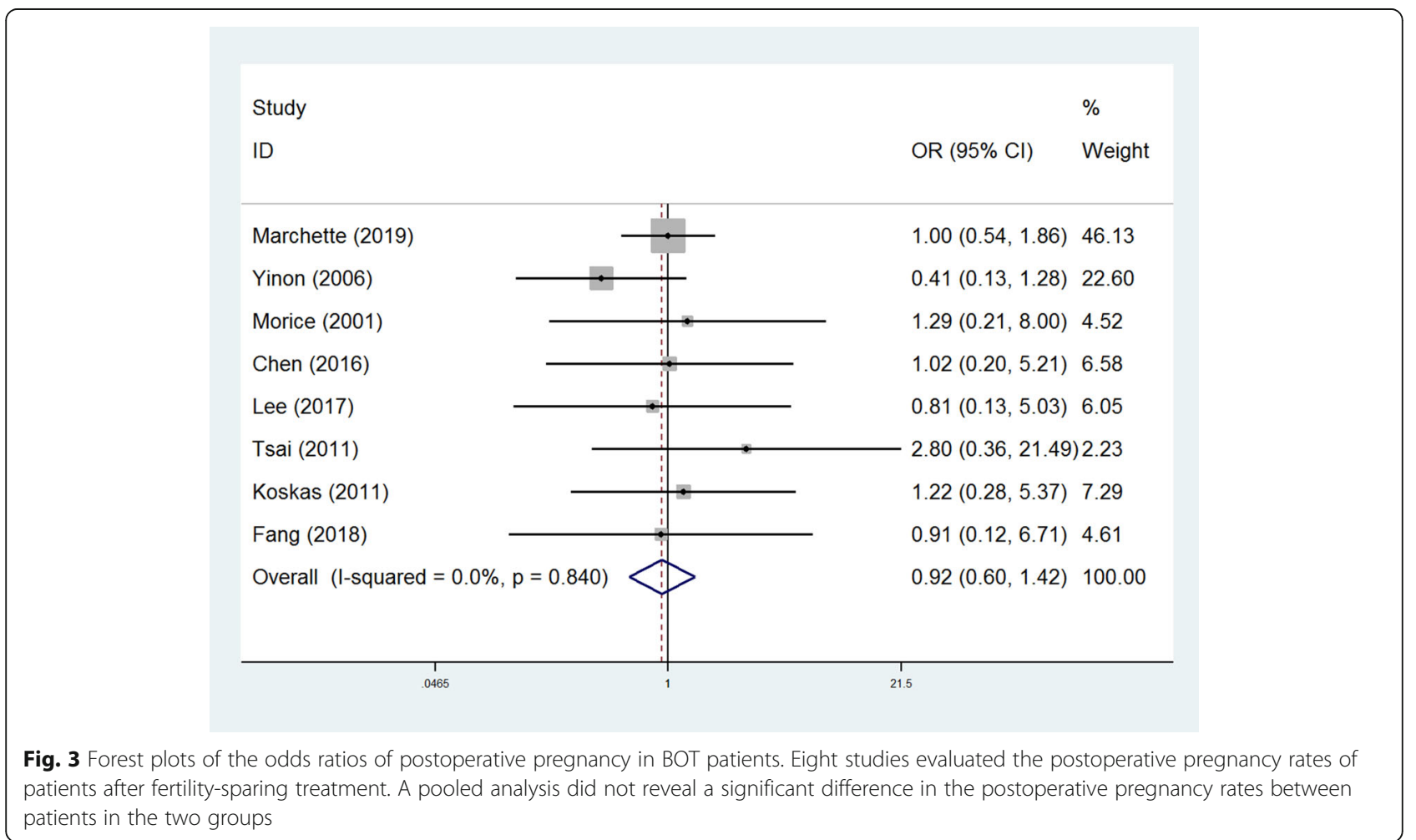


investigated the effects of four kinds of FSTs including unilateral adnexectomy, unilateral cystectomy, unilateral adnexectomy plus contralateral cystectomy, and bilateral cystectomy in patients with BOTs [20]. Patients in the unilateral cystectomy group had a higher relapse rate (which was increased to 9.3\%) and shorter interval of relapse (which was decreased to 22.7 months) compared with those in the unilateral adnexectomy group. Nevertheless, Song and colleagues showed in their study that patients receiving bilateral cystectomy had a significantly higher cumulative rate of pregnancy compared with patients receiving unilateral adnexectomy plus contralateral cystectomy (14/15 versus 9/17) [19]. According to these results, cystectomy can be considered as a method for surgery in patients with extremely strong expectations of pregnancy. Even so, in our study, the pooled analysis showed a significantly higher risk of recurrence in patients with unilateral/bilateral cystectomy compared with salpingo-oophorectomy. More importantly, the rate of postoperative pregnancy was similar between these two surgical approaches. It is preliminarily suggested that salpingo-oophorectomy may be a better choice for BOT patients.

Many previous reports advocated the advantage of salpingo-oophorectomy in lower recurrence rate compared with cystectomy $[25,26,31]$. However, other studies did not detect a significant difference in postoperative relapse rate between patients with cystectomy and salpingo-oophorectomy [20, 24, 32]. Some scholars argued that the main reason for this discrepancy was the difference in the sample size of studies [32], which should be further clarified in future studies with strict design. Our meta-analysis here confirmed that the risk of recurrence was indeed significantly higher in patients with cystectomy than those with salpingo-oophorectomy $(\mathrm{OR}=2.02,95 \% \mathrm{CI}, 1.59-2.57)$. In addition, the subgroup analysis for the four studies, in which HRs were calculated, further supported a higher pooled $H R(H R=2.00$, 95\% CI, 1.11-3.58) for patients who underwent cystectomy compared with those receiving salpingooophorectomy. Therefore, our study verified a preference for salpingo-oophorectomy than cystectomy for surgery decision-making in patients with BOTs.

\section{Limitations}

There are some limitations of this meta-analysis. First of all, the included studies were retrospective cohort studies, which limited the strength of evidence levels. Secondly, only 4 studies evaluated the HRs and 95\% CI for BOT recurrence and there was curtain heterogeneity among these studies. Further considerations on the source of heterogeneity should be paid attention to when conducting related studies to confirm these results. Thirdly, since the diagnoses were confirmed by pathological examination after surgery, the selection bias was inevitably existed in the included studies. Finally, we did not investigate and compare the survival data between patients who underwent the two different surgical procedures, which should be clarified in further analyses.

\section{Conclusion}

On the basis of our pooled analysis of previous studies, this study confirmed that compared with the unilateral/ bilateral cystectomy, the unilateral salpingooophorectomy significantly reduces the risk of postoperative recurrence in patients with BOT, and it does not influence the pregnancy of patients after surgery. For BOT patients with the expectation of pregnancy, unilateral salpingo-oophorectomy may be a preferred choice for treatment.

\section{Supplementary Information}

The online version contains supplementary material available at https://doi. org/10.1186/s12957-021-02241-2.

Additional file 1: Supplementary Figure 1: Begg's funnel plot with pseudo 95\% confidence limits

Additional file 2: Supplementary Figure 2: Egger's publication bias plot

Additional file 3: Supplementary Figure 3: Funnel plot with pseudo 95\% confidence limits

Additional file 4: Supplementary Figure 4: Funnel plot with pseudo 95\% confidence limits

\section{Acknowledgements}

Not applicable.

Authors' contributions

Peng Wang and Lei Fang Zhao conceived and designed the study, conducted the literature review and drafted the manuscript. All authors have read and approved the final manuscript.

\section{Funding}

Not applicable.

Availability of data and materials

The current study was based on the results of relevant published studies.

\section{Declarations}

Ethics approval and consent to participate

Not applicable.

Consent for publication

Not applicable.

Competing interests

No competing interests exist in this manuscript.

Received: 16 December 2020 Accepted: 13 April 2021

Published online: 21 April 2021

References

1. Hart WR. Borderline epithelial tumors of the ovary. Mod Pathol. 2005; 18(Suppl 2):S33-50. https://doi.org/10.1038/modpathol.3800307.

2. Skirnisdottir I, Garmo H, Wilander E, Holmberg L. Borderline ovarian tumors in Sweden 1960-2005: trends in incidence and age at diagnosis compared 
to ovarian cancer. Int J Cancer. 2008;123(8):1897-901. https://doi.org/10.1 002/ijc.23724.

3. Trope CG, Kaern J, Davidson B. Borderline ovarian tumours. Best Pract Res Clin Obstet Gynaecol. 2012;26(3):325-36. https://doi.org/10.1016/j.bpobgyn.2 011.12.006.

4. Hauptmann S, Friedrich K, Redline R, Avril S. Ovarian borderline tumors in the 2014 WHO classification: evolving concepts and diagnostic criteria. Virchows Arch. 2017;470(2):125-42. https://doi.org/10.1007/s00428-016-20408.

5. Heintz AP, Odicino F, Maisonneuve P, et al. Carcinoma of the ovary. FIGO 26th Annual Report on the Results of Treatment in Gynecological Cancer. Int J Gynaecol Obstet. 2006;95(Suppl 1):S161-92.

6. du B, Trillsch F, Mahner S, et al. Management of borderline ovarian tumors. Ann Oncol. 2016;(Suppl 1):i20-2.

7. Barani M, Bilal M, Sabir F, Rahdar A, Kyzas GZ. Nanotechnology in ovarian cancer: diagnosis and treatment. Life Sci. 2021;266:118914. https://doi.org/1 0.1016/j.lfs.2020.118914.

8. Lalwani N, Shanbhogue AK, Vikram R, Nagar A, Jagirdar J, Prasad SR. Current update on borderline ovarian neoplasms. AJR Am J Roentgenol. 2010;194(2): 330-6. https://doi.org/10.2214/AJR.09.3936.

9. Trillsch F, Mahner S, Ruetzel J, Harter P, Ewald-Riegler N, Jaenicke F, et al. Clinical management of borderline ovarian tumors. Expert Rev Anticancer Ther. 2010;10(7):1115-24. https://doi.org/10.1586/era.10.90.

10. Frega A, Coluccia AC, Di Martino G, et al. Borderline ovarian tumors, fertilitysparing surgery and pregnancy outcome. Eur Rev Med Pharmacol Sci. 2014; 18(2):281-4.

11. Smaldone GM, Richard SD, Edwards RP. Pregnancy outcomes after conservative surgical management of ovarian neoplasms treated at a single institution. Int J Gynecol Cancer. 2010;20(6):926-31. https://doi.org/10.1111/ IGC.0b013e3181e5c45a.

12. Uzan C, Muller E, Kane A, Rey A, Gouy S, Bendiffallah S, et al. Prognostic factors for recurrence after conservative treatment in a series of 119 patients with stage I serous borderline tumors of the ovary. Ann Oncol. 2014;25(1):166-71. https://doi.org/10.1093/annonc/mdt430.

13. Song T, Lee $Y Y$, Choi CH, Kim TJ, Lee JW, Bae DS, et al. Borderline ovarian tumor in women aged $>/=65$ years: impact on recurrence and survival. Eur J Obstet Gynecol Reprod Biol. 2015;184:38-42. https://doi.org/10.1016/j. ejogrb.2014.10.001

14. Louis AR, Gupta SK, Gouda C, Gupta G. Fatal hematogenous relapse of mucinous borderline ovarian tumor of intestinal type. Indian J Med Paediatr Oncol. 2013;34(2):134-5. https://doi.org/10.4103/0971-5851.116222.

15. Darai E, Fauvet R, Uzan C, Gouy S, Duvillard P, Morice P. Fertility and borderline ovarian tumor: a systematic review of conservative management, risk of recurrence and alternative options. Hum Reprod Update. 2013;19(2): 151-66. https://doi.org/10.1093/humupd/dms047.

16. Yoon MS, Park W, Huh SJ, Kim HJ, Kim YS, Kim YB, et al. Impact of paraaortic lymphadenectomy for endometrial cancer with positive pelvic lymph nodes: a Korean Radiation Oncology Group study (KROG 13-17). Eur J Surg Oncol. 2016;42(10):1497-505. https://doi.org/10.1016/j.ejso.2016.07.003.

17. van Meurs HS, van Lonkhuijzen LR, Limpens J, et al. Hormone therapy in ovarian granulosa cell tumors: a systematic review. Gynecol Oncol. 2014 134(1):196-205. https://doi.org/10.1016/j.ygyno.2014.03.573.

18. Ureyen I, Karalok A, Tasci T, Turkmen O, Boran N, Tulunay G, et al. The factors predicting recurrence in patients with serous borderline ovarian tumor. Int J Gynecol Cancer. 2016;26(1):66-72. https://doi.org/10.1097/IGC.00000000000000568.

19. Song T, Choi CH, Park HS, Kim MK, Lee YY, Kim TJ, et al. Fertility-sparing surgery for borderline ovarian tumors: oncologic safety and reproductive outcomes. Int J Gynecol Cancer. 2011;21(4):640-6. https://doi.org/10.1097/ IGC.0b013e3182129842.

20. Chen RF, Li J, Zhu TT, Yu HL, Lu X. Fertility-sparing surgery for young patients with borderline ovarian tumors (BOTs): single institution experience. J Ovarian Res. 2016;9(1):16. https://doi.org/10.1186/s13048-016-0226-y.

21. Fang C, Zhao L, Chen X, Yu A, Xia L, Zhang P. The impact of clinicopathologic and surgical factors on relapse and pregnancy in young patients $(</=40$ years old) with borderline ovarian tumors. BMC Cancer. 2018;18(1):1147. https://doi.org/10.1186/s12885-018-4932-2.

22. Poncelet C, Fauvet R, Boccara J, Darai E. Recurrence after cystectomy for borderline ovarian tumors: results of a French multicenter study. Ann Surg Oncol. 2006;13(4):565-71. https://doi.org/10.1245/ASO.2006.12.024.

23. Lee SY, Choi MC, Kwon BR, Jung SG, Park H, Joo WD, et al. Oncologic and obstetric outcomes of conservative surgery for borderline ovarian tumors in women of reproductive age. Obstet Gynecol Sci. 2017;60(3):289-95. https:// doi.org/10.5468/ogs.2017.60.3.289.

24. Kanat-Pektas M, Ozat M, Gungor T, Dikici T, Yilmaz B, Mollamahmutoglu L. Fertility outcome after conservative surgery for borderline ovarian tumors: a single center experience. Arch Gynecol Obstet. 2011;284(5):1253-8. https:// doi.org/10.1007/s00404-010-1804-7.

25. Koskas M, Uzan C, Gouy S, Pautier P, Lhomme C, Haie-Meder C, et al. Fertility determinants after conservative surgery for mucinous borderline tumours of the ovary (excluding peritoneal pseudomyxoma). Hum Reprod. 2011;26(4):808-14. https://doi.org/10.1093/humrep/deq399.

26. Tsai HW, Ko CC, Yeh CC, Chen YJ, Twu NF, Chao KC, et al. Unilateral salpingo-oophorectomy as fertility-sparing surgery for borderline ovarian tumors. J Chin Med Assoc. 2011;74(6):250-4. https://doi.org/10.1016/j.jcma.2 011.04.003.

27. Delle Marchette M, Ceppi L, Andreano A, Bonazzi CM, Buda A, Grassi T, et al. Oncologic and fertility impact of surgical approach for borderline ovarian tumours treated with fertility sparing surgery. Eur J Cancer. 2019;111:61-8. https://doi.org/10.1016/j.ejca.2019.01.021.

28. De laco P, Ferrero A, Rosati F, et al. Behaviour of ovarian tumors of low malignant potential treated with conservative surgery. Eur J Surg Oncol. 2009;35(6):643-8. https://doi.org/10.1016/j.ejso.2008.09.011.

29. Suh-Burgmann E. Long-term outcomes following conservative surgery for borderline tumor of the ovary: a large population-based study. Gynecol Oncol. 2006;103(3):841-7. https://doi.org/10.1016/j.ygyno.2006.05.014.

30. Romagnolo C, Gadducci A, Sartori E, Zola P, Maggino T. Management of borderline ovarian tumors: results of an Italian multicenter study. Gynecol Oncol. 2006;101(2):255-60. https://doi.org/10.1016/j.ygyno.2005.10.014.

31. Morice P, Camatte S, El Hassan J, Pautier P, Duvillard P, Castaigne D. Clinical outcomes and fertility after conservative treatment of ovarian borderline tumors. Fertil Steril. 2001;75(1):92-6. https://doi.org/10.1016/S0015-0282 (00)01633-2.

32. Yinon Y, Beiner ME, Gotlieb WH, Korach Y, Perri T, Ben-Baruch G. Clinical outcome of cystectomy compared with unilateral salpingo-oophorectomy as fertility-sparing treatment of borderline ovarian tumors. Fertil Steril. 2007; 88(2):479-84. https://doi.org/10.1016/j.fertnstert.2006.11.128.

33. Akeson M, Zetterqvist BM, Dahllof $K$, Jakobsen AM, Brannstrom M, Horvath G. Population-based cohort follow-up study of all patients operated for borderline ovarian tumor in western Sweden during an 11-year period. Int J Gynecol Cancer. 2008;18(3):453-9. https://doi.org/10.1111/j.1525-1438.2007. 01051.x.

34. Lin JE, Seo S, Kushner DM, Rose SL. The role of appendectomy for mucinous ovarian neoplasms. Am J Obstet Gynecol. 2013;208(1):46 e41-4.

35. Anfinan N, Sait K, Ghatage P, Nation J, Chu P. Ten years experience in the management of borderline ovarian tumors at Tom Baker Cancer Centre. Arch Gynecol Obstet. 2011;284(3):731-5. https://doi.org/10.1007/s00404-01 0-1713-9.

36. Silva EG, Gershenson DM, Malpica A, Deavers M. The recurrence and the overall survival rates of ovarian serous borderline neoplasms with noninvasive implants is time dependent. Am J Surg Pathol. 2006;30(11): 1367-71. https://doi.org/10.1097/01.pas.0000213294.81154.95.

37. Swanton A, Bankhead CR, Kehoe S. Pregnancy rates after conservative treatment for borderline ovarian tumours: a systematic review. Eur J Obstet Gynecol Reprod Biol. 2007;135(1):3-7. https://doi.org/10.1016/j.ejogrb.2007. 05.011 .

\section{Publisher's Note}

Springer Nature remains neutral with regard to jurisdictional claims in published maps and institutional affiliations. 